\title{
HUBUNGAN KECEPATAN LARI DAN DAYA LEDAK OTOT TUNGKAI DENGAN \\ HASIL LOMPAT JAUH GAYA MENGGANTUNG PADA MAHASISWA KULIAH OLAHRAGA PRESTASI ATLETIK FAKULTAS ILMU KEOLAHRAGAAN UNIVERSITAS NEGERI JAKARTA
}

\author{
Muhammad Yudas Azhari \\ Bambang Sujiono dan Roy Widyonarto
}

ABSTRAK. Tujuan dari penelitian ini adalah untuk mengetahui adanya (1) hubungan kecepatan
lari dengan hasil lompat jauh gaya menggantung, (2) hubungan daya ledak otot tungkai dengan
hasil lompat jauh gaya menggantung dan (3) hubungan kecepatan lari dan daya ledak otot tungkai
dengan hasil lompat jauh gaya menggantung secara bersama-sama pada mahasiswa Kuliah
Olahraga Prestasi Atletik Fakultas Ilmu Keolahragaan Universitas Negeri Jakarta.
Pengambilan data ini dilaksanakan tanggal 20 Desember 2016 di Stadion Atletik Pemuda GOR Rawamangun Jakarta Timur. Metode penelitian yang digunakan adalah deskriptif menggunakan teknik studi korelasi, dengan sampel sebanyak 30 mahasiswa Kuliah Olahraga Prestasi Atletik Fakultas Ilmu Keolahragaan Universitas Negeri Jakarta dari jumlah 90 mahasiswa terdaftar sebagai anggota dengan teknik pengambilan sampel menggunakan purposive sampling.

Instrumen penelitian adalah dengan melakukan pengukuran terhadap variabel-variabel terdiri dari tiga tes, yaitu tes sprint 20 meter untuk mengetahui kecepatan lari, tes standing broad jump untuk mengetahui daya ledak otot tungkai, dan yang terakhir tes lompat jauh gaya menggantung. Teknik analisis yang digunakan adalah mencari regresi lalu menghitung korelasi dari variabel dengan membandingkan dengan f-tabel pada taraf signifikan 0,05.

Berdasarkan analisis hasil penelitian diperoleh:

1. hubungan antara kecepatan lari dengan hasil lompat jauh gaya menggantung, dengan persamaan garis linier $=10,37-1,59$, koefisien korelasi (ry2) $=0,87$, yang berarti tingkat hubungannya masuk dalam kategori tinggi. Koefisien determinasi $\left(r y 1^{2}\right)=0,749$ yang berarti variabel kecepatan lari memberikan sumbangan dengan hasil lompat jauh gaya menggantung sebesar 74,90\%.

2. hubungan antara daya ledak otot tungkai dengan hasil lompat jauh gaya menggantung, dengan persamaan garis linier $\hat{Y}=0,35+1,64 \mathrm{X} 2$, koefisien korelasi (ry1) $=0,75$, yang berarti tingkat hubungannya masuk dalam kategori sangat tinggi. Koefisien determinasi $\left(\right.$ ry $\left.1^{2}\right)=0,569$, yang berarti variabel daya ledak otot tungkai memberikan sumbangan terhadap hasil lompat jauh gaya menggantung sebesar 56,90\%.

3. hubungan antara kecepatan lari dan daya ledak otot tungkai dengan hasil lompat jauh gaya menggantung, dengan persamaan garis linier $\hat{Y}=7,87-1,27+0,82$, koefisien korelasi Ry1-2 $=0,88$, yang berarti tingkat hubungannya masuk dalam kategori sangat tinggi. Koefisien determinasi (Ry1-2) ${ }^{2}=0,771$ yang berarti variabel kecepatan lari dan daya ledak otot tungkai dengan hasil lompat jauh gaya menggantung memberikan sumbangan sebesar $77,10 \%$. Dalam penelitian ini kecepatan lari dan daya ledak otot tungkai secara bersama-sama memberikan kontribusi sebesar 77,10\% pada hasil lompat jauh gaya menggantung. Sisanya sebesar $23,90 \%$ ditentukan oleh faktor lainnya.

Kata Kunci : Lompat, Daya Ledak, Kecepatan 


\section{PENDAHULUAN}

Lompat merupakan salah satu cabang olahraga atletik. Lompat juga merupakan salah satu bagian dari berbagai gerakan dalam olahraga lain. Misalnya dalam olahraga voli, pemain yang melakukan smash dengan melompat ke atas untuk menjangkau bola. Itu salah satu hal yang penting dalam olahraga bola voli. Lompat dalam atletik juga sangat populer dari dunia olahraga, misalnya dalam perlombaan lompat jauh, para atlet bersaing untuk menunjukan kekuatan dirinya dalam lompat semaksimal mungkin.

Lompat jauh merupakan salah satu nomor lompat dari cabang olahraga atletik. Lompat jauh adalah bentuk gerakan yang merupakan rangkaian urutan gerakan yang dilakukan untuk mencapai jarak sejauhjauhnya yang merupakan hasil dari kecepatan horizontal yang dibuat sewaktu awalan dengan daya vertikal yang dihasilkan oleh kekuatan otot-otot tungkai. Biasanya pelatih dan atlet menganggap bahwa atlet lari yang paling cepat adalah calon terbaik untuk lompat jauh, tetapi nomor ini tidak sesederhana itu, perhatian khusus pada halhal teknis ternyata memberikan keuntungan bagi atlet pada saat perlombaan. Memerlukan waktu latihan yang lama bagi para atlet untuk menguasai tahapan lompat jauh. Mereka harus menyempurnakan lari awalan yang efektif, posisi tubuh yang tepat selama bertolak, melayang, dan mendarat.

$$
\text { Sehingga ini menyulitkan }
$$

mahasiswa dalam melakukan tolakan dalam lompat jauh. Ini dipengaruhi oleh kecepatan lari dan daya ledak otot tungkai. Agar mahasiswa dapat mengkombinasikan daya ledak otot tungkai dan kecepatan lari sehingga menemukan tolakan yang tepat dan hasil yang maksimal.

Dalam pelaksanaan lompat jauh gaya menggantung di Klub Olahraga Prestasi Atletik banyak menemui kendala diantaranya :

a. Mahasiswa mengalami kesulitan dalam pemahaman gerakan lompat jauh gaya menggantung

b. Mahasiswa sulit dalam menentukan langkah pada saat awalan hingga akhirnya banyak siswa yang melewati papan tolakan pada saat melakukan tolakan,

c. Pada saat menolak mahasiswa lebih sering tidak menolak saat melakukan tolakan di papan.

Hubungan gerakan merupakan salah satu ciri-ciri koordinasi yang sangat penting dan perlu dipahami oleh mahasiswa Klub Olahraga Prestasi Atletik, karena hubungan gerakan merupakan salah satu dasar untuk dapat menguasai bentuk-bentuk keterampilan motorik olahraga. Hubungan gerakan merupakan suatu proses transfer impuls tenaga dari suatu bagian tubuh ke bagian tubuh yang lain atau proses transfer impuls dari suatu alat gerak ke alat gerak yang lain, sehingga terjadi hubungan gerakan.

Dengan mengetahui permasalahan di atas maka saya akan melakukan penelitian tentang hubungan kecepatan lari dan daya ledak otot tungkai dengan hasil lompat jauh gaya menggantung. Apakah terdapat hubungan antara kecepatan lari dan daya ledak otot tungkai dengan lompat jauh.

\section{LOMPAT JAUH GAYA MENGGANTUNG}

Lompat adalah suatu gerakan mengangkat tubuh dari suatu titik ke titik yang lain yang lebih jauh atau tinggi dengan ancang-ancang lari cepat atau lambat dengan menumpu satu kaki dan mendarat dengan kaki atau anggota tubuh lainnya dengan keseimbangan yang baik, sedangkan lompat jauh adalah suatu bentuk gerakan melompat mengangkat kaki ke atas ke depan dalam upaya membawa titik berat badan selama mungkin di udara (melayang di udara) yang dilakukan dengan cepat dengan jalan melakukan tolakan pada satu kaki untuk mencapai jarak yang sejauh-jauhnya.

Lompat Jauh adalah salah satu nomor atletik yang dilakukan dengan melompat di bak pasir yang sudah ditentukan ukurannya dengan menggunakan salah satu kaki yang kuat sebagai tumpuannya. Untuk melakukan lompatan sejauh-jauhnya, perlu dilakukan awalan yang baik. Maka untuk dapat mencapai jarak lompatan itu dengan jauh, terlebih dahulu harus memahami unsur-unsur pokok pada lompat. 
Lompat Jauh adalah suatu bentuk gerakan melompat yang diawali dengan gerakan horizontal dan diubah ke gerakan vertikal dengan jalan melakukan tolakan pada satu kaki yang terkuat untuk memperoleh jarak yang sejauh-jauhnya. Tujuan dari lompat jauh adalah melompat sejauh-jauhnya dengan memindahkan seluruh tubuh dari titik tertentu ke titik lainnya. Maka dibutuhkan koordinasi yang baik untuk melakukan keterampilan lompat jauh. Koordinasi adalah kemampuan untuk melakukan gerakan dengan berbagai tingkat kesukaran dengan cepat dan efisien dan penuh ketepatan.

Lompatan horizontal, yaitu lompat jauh memerlukan mekanisme lari yang baik dan juga kecepatan optimal saat take off (bertolak). Lompat jauh adalah suatu nomor atletik yang seringkali hanya mendapat sedikit perhatian. Biasanya para pelatih dan atlet menganggap bahwa atlet lari yang paling cepat adalah calon terbaik untuk lompat jauh, tetapi sebenarnya nomor ini tidak sesederhana itu. Perhatian yang khusus pada hal-hal teknis ternyata memberikan keuntungan bagi atlet saat perlombaan. Memerlukan waktu dan latihan yang cukup lama bagi para atlet untuk menguasai tahapan lompat jauh, mereka harus menyempurnakan lari awalan yang efektif, posisi tubuh yang tepat selama bertolak melayang, dan mendarat.

Menurut Edy Suparman, faktor yang mempengaruhi keterampilan lompat jauh adalah kecepatan, kekuatan, daya ledak, keseimbangan, keterampilan, koordinasi.

a. Kecepatan (Speed) adalah kemampuan untuk memindahkan sebagian tubuh atau seluruhnya dari awalan sampai dengan pendaratan. Atau bertumpu pada papan / balok sewaktu melakukan lompatan, kecepatan banyak ditentukan kekuatan dan fleksibelitas.

b. Kekuatan (Strength) adalah jumlah tenaga yang dapat dihasilkan oleh kelompok otot pada kontraksi maksimal pada saat melakukan pekerjaan atau latihan dalam melakukan lompatan.

c. Daya ledak adalah kemampuan otot dalam melakukan tolakan untuk membawa tubuh melayang di udara saat lepas dari balok tumpu.

d. Keseimbangan adalah kemampuan untuk mempertahankan suatu sikap tubuh tertentu secara benar digunakan dari awal melakukan lompatan sampai selesai melakukan lompatan.

e. Keterampilan adalah kemampuan untuk melakukan suatu gerakan motorik secara benar.

f. Koordinasi adalah hal yang harus dimiliki oleh seorang atlet untuk dapat mengkoordinasikan gerakan yaitu gerakan maju dengan kemudian membawa gerakan dengan kebutuhan naik.

Macam-macam gaya lompat jauh diantaranya gaya jongkok, gaya menggantung di udara, dan gaya berjalan di udara. Gaya Jongkok adalah badan melenting ke depan kedua lengan lurus ke depan kedua kaki rapat di depan. Gaya berjalan di udara (walking in the air ) badan melenting ke depan kedua lengan mengayun seperti orang lari kedua kaki mengayun seperti orang berjalan. Gaya menggantung ( Hang Style/Schnepper ).

Badan melenting ke belakang kedua lengan lurus $k e$ atas di samping telinga kedua kaki hampir rapat di belakang badan. Dari pendapat di atas dapat disimpulkan bahwa gaya untuk mempertahankan diri di udara (melayang) ada tiga, gaya tersebut adalah Gaya Jongkok (sail style), Gaya Menggantung atau Gaya Lenting (The Hang Style), dan Gaya Berjalan di Udara (hitch kick style/ walking in the air). Lompat Jauh Gaya Menggantung adalah gaya yang diperoleh dengan cara merentangkan tubuh setelah take off (lepas landas), dengan kedua tungkai diseret. Tujuan utama melayang di udara dengan menggunakan teknik the hang (Mengantung) adalah mendapatkan keseimbangan pada saat melayang dan memperoleh posisi mendarat (landing) yang efisien dan mengurangi arah rotasi dengan merentangkan tubuh pada saat melayang.

Menurut Peter Thompson, ditinjau dari aspek biomekanika dari nomor lompat pada atletik, dapat ditinjau dari tiga parameter :(1) Kecepatan tolakan (velocity at take off), (2) Sudut tolakan (angle a take 
off), (3) Ketinggian pusat berat badan saat tolakan (height of the centre of mass at take off).

Sedangkan menurut Dikdik Zafar Sidik, tinggi titik pusat massa ditentukan oleh tinggi badan altet meskipun dipengaruhi oleh posisi pada saat bertumpu. Kecepatan melakukan tolakan dan sudut tolakan adalah hasil dari gerakan sebelum dan selama melakukan tolakan, sehingga tolakan ini sangat penting dalam semua nomor lompat. Dengan adanya kecepatan yang baik maka akan menghasilkan daya ledak yang besar. Setelah itu akan menciptakan sudut tolakan yang baik untuk mendapatkan gerakan melayang yang maksimal dan mencapai jarak terbaik yang dihasilkan oleh pelompat.

Urutan gerakan dalam lompat jauh dapat dibagi menjadi empat fase yaitu : (1) Awalan (Approach), (2) Lompat/ tolakan (Take off), (3) Melayang (Flight), (4) Mendarat (Landing). Dalam lompat jauh, hasil akhir ditentukan oleh kecepatan saat melakukan awalan untuk mendapatkan kecepatan maksimal.

Saat mendekati papan tolakan, awalan yang baik adalah menggunakan kecepatan dari lambat ke cepat atau biasa disebut dengan akselerasi. Karakteristik dalam melakukan awalan yang baik adalah cepat, ketepatan dan konsisten, dan persiapan atlet dalam melakukan take off yang baik. Dan karakteristik dalam melakukan take off yang baik adalah posisi atlet dalam posisi tinggi, posisi kaki take off dalam keadaan tegap dan cepat, posisi lutut dalam keadaan lurus dengan pinggang, yang bertujuan untuk memperluas jangkauan pinggang, lutut, dan pergelangan kaki.

$$
\text { Kembali Peter Thompson }
$$
mengemukakan saat melakukan teknik lompat jauh dalam nomor atletik harus membentuk rangkaian yang terdiri dari beberapa elemen yaitu :

(a) Perubahan awalan untuk persiapan take off, (b) Pergerakan dalam fase melayang di udara, (c) Mendarat. Poin yang harus ditekankan adalah : (a) Meningkatkan frekuensi langkah dalam mendekati akhir awalan, (b) Posisi kaki yang aktif saat melakukan take off, (c) Melakukan take off dengan kuat, (d) Ekstensi penuh pada pergelangan kaki, lutut, dan pinggang saat melakukan take off. Poin yang harus dihindari adalah : (a) Menurukan kecepatan pada saat mendekati akhir awalan, (b) Merendahkan pusat gaya berat dalam persiapan take off, (c) Melemaskan langkah dengan menggunakan tumit saat take off, (d) melompat dengan posisi berdiri, (e) Melakukan lipatan terlalu cepat saat melayang di udara.

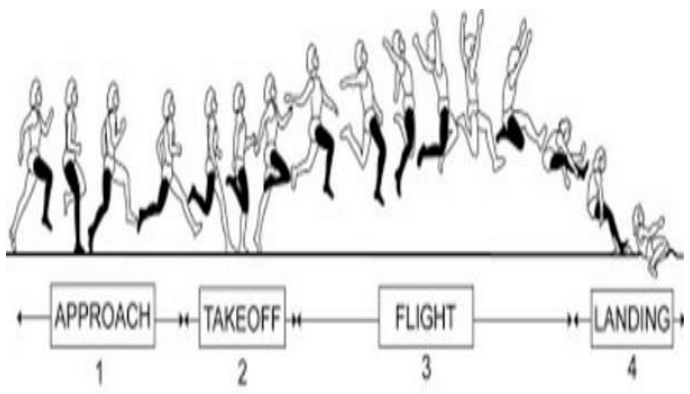

Gambar 1.Rangkaian Gerak LompatJauh Sumber :Peter Thompshon,Run, Jump, Throw, The Official IAAF Guide to Teaching Athletics, (IAAF : Warners Midlands plc, 2009)

Awalan

Objek yang penting dalam melakukan awalan adalah menghasilkan kontrol kecepatan maksimum pada papan tolakan secara tepat. Ketepatan dan konsisten saat melakukan awalan lari sangat diperlukan. Kebiasaan yang sering terjadi apaila melakukan take off adalah melakukan take off di belakang papan tolakan,itu menunjukan persiapan yang tidak baik.

Secara fundamental, mekanisme lari yang baik, ritme dan repetisi akan menghasilkan awalan lari yang konsisten
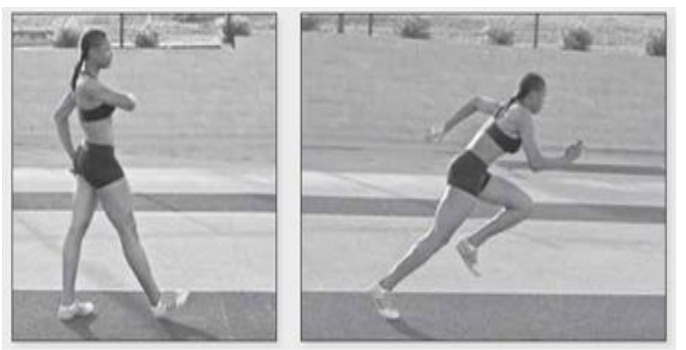

Gambar 2. Fase Gerakan Awalan Yang Di awali Dengan Lari

Sumber : Ed Jacoby, Winning Jump and

Pole Vault (USA : Human Kinetics, 2009) 
Tolakan (Take-Off)

Tolakan adalah perubahan atau perpindahan gerakan dari gerakan horizontal ke gerakan vertikal yang dilakukan secara cepat. Tumpuan atau tolakan kaki harus kuat agar tercapai tinggi lompatan yang cukup tanpa kehilangan kecepatan laju. Kaki ayun digerakkan secara aktif agar membantu menaikkan badan dan menjaga keseimbangan berat badan sedikit kedepan titik tumpuan. Pada saat menumpu atau melakukan tolakan, badan sudah condong kedepan.

Bagi altet untuk melompat dengan kecepatan maksimal, harus merendahkan pangkal paha atau panggul kaki menekuk di lutut dan paha. Maksudnya, tidak dapat melompat dengan kaki yang lurus. Atlet seharusnya tidak lamban dalam melakukan gerakan ini, tetapi mereka harus menggunakan kekuatan yang maksimal dan kaki tolakan harus cepat. Kesalahan yang sering terjadi adalah ketika melakukan gerakan langkah tersebut, atlet langsung berhenti dan kehilangan kecepatan sambil menjatuhkan pangkal paha.
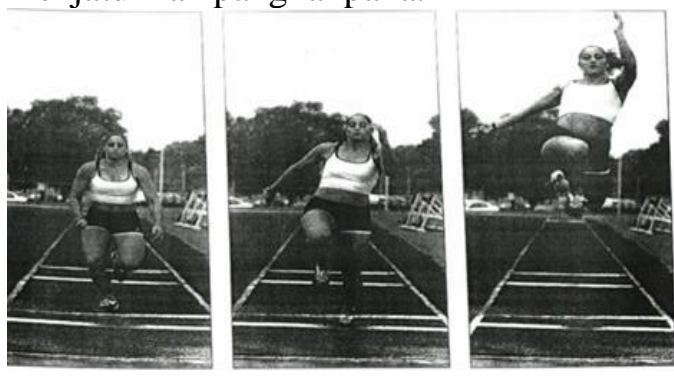

Gambar 3. Fase Gerakan Tolakan Dilihat Dari Depan

Sumber :Mark Guthrie, Sukes Melatih Atletik (USA : Human Kinetics, 2008)

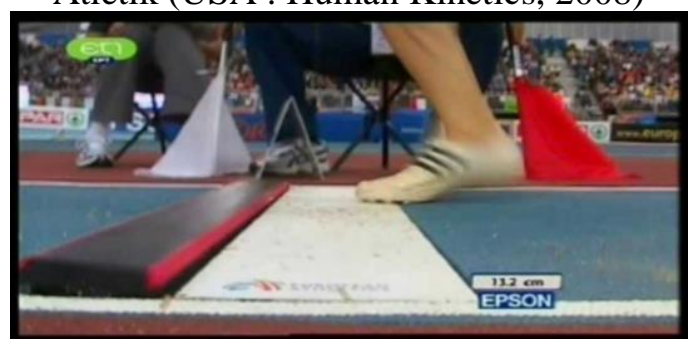

Gambar 4. Fase Menolak (Take-Off) Sumber;board.google.com,https://www.goo gle.com/search?q=board+in+long+jump\&s ource.com. Diakses tanggal 15 Desember 2016.
Menurut gambar diatas menunjukan bahwa atlet melakukan tolakan dibelakang papan tolakan, itu biasanya terjadi karena kesalahan perhitungan check mark atau perubahan tempo lari dari awalan sampai papan tumpuan.

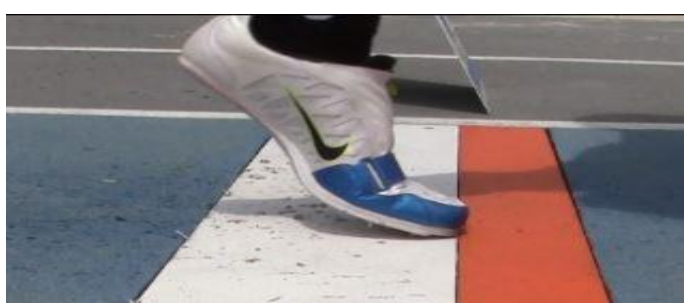

Gambar 5. Fase Menolak (Take Off) Yang Tepat

Sumber;boardgoogle.com,https://www.goo gle.com/search?q=board+in+long+jump\&s ource.coDiakses tanggal15 desember 2016

Menurut gambar di atas menunjukan bahwa atlet melakukan tolakan tepat pada papan, dan ini di anggap gerakan yang sangat baik, karena sesuai teori, gerakan ini tepat karena check mark dan tempo lari sesuai dengan frekuensi yang di tentukan. Sehingga mendapatkan hasil jarak yang diukur sesuai.

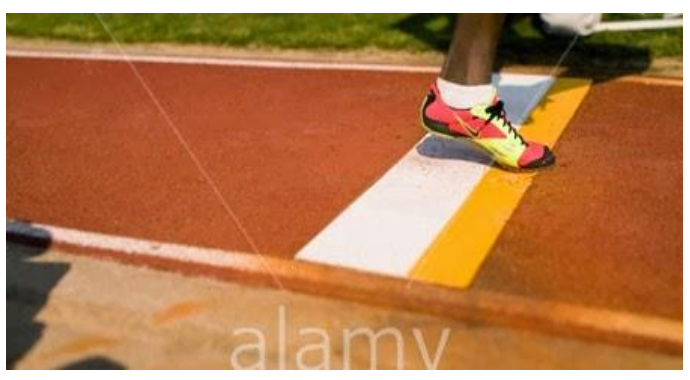

Gambar 6. (Take-Off) Tidak Sah

Sumber:https://www.google.com/search?q= board+in+long + jump\&source $=1 \mathrm{nms} \&$ tbm $=\mathrm{i}$ sch\&sa. Di akses tanggal 15 Desember 2016.

Menurut gambar diatas menunjukan bahwa atlet melakukan tolakan terlalu jauh pada papan, dan ini di anggap gerakan yang tidak sah. Gerakan ini terjadi karena keslahan pada check mark atau tempo lari yang tidak stabil mengakibatkan gerakan.yang terlalu jauh kedepan pada papan tolakan dan mengakibatkan lompatan yang tidak sah. 


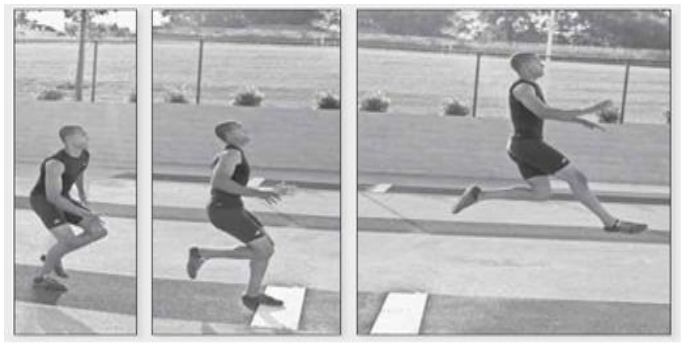

Gambar 7. Fase Gerakan Tolakan Dilihat Dari Samping

Sumber :Ed Jacoby, Winning Jump and Pole Vault (USA : Human Kinetics, 2009)

Melayang

Saat altet meninggalkan tanah (papan tolakan), dia telah melakukan akurasi yang dia dapatkan yang sudah diperhitungkan. Kecepatan saat melakukan tolakan dan sudut tolakan menentukan jarak yang ditempuh. Pada saat di udara tidak ada gerakan yang dilakukan seorang atlet yang dapat menambah jarak di udara, walaupun ada hal-hal yang dapat dilakukan atlet di udara untuk mengurangi jarak tempuh.

Tujuannya adalah untuk mendapatkan sebuah posisi yang maksimal terhadap jarak tempuh lompatan. Pada posisi tolakan, atlet memiliki pusat gaya berat, yaitu di pangkal paha di depan kaki tolakan. Hal ini menyebabkan pengaruh rotasi ke depan, maksudnya kepala dan pundak atlet secara alami bergerak maju dan mundur, yang menyebabkan kaki bergerak ke bawah dan ke belakang.

Dengan menjatuhkan kaki sebelum waktunya menyebabkan atlet kehilangan jarak tempuh. Tujuan dari teknik melayang ini adalah untuk mengurangi putaran depan. Beberapa gaya telah dikembangkan untuk menyempurnakan teknik ini. Biasanya atlet melakukan gaya "tendangan menyentak" atau hitch kick, atau pun gaya "menggantung" atau "schneper".

Dalam kedua gaya ini, tubuh atlet berada dalam posisi tegak lurus. Atlet melebarkan lengan dan kaki sambil menggunakan pengungkit yang panjang dari pusat gaya berat sehingga putaran depan dapat dikurangi. Di papan tolak seorang altet melakukan posisi melipat tubuh dan kaki cepat ke belakang dan melakukan ke arah kebalikan. Semakin dekat lipatan atlet di sekeliling pusat gaya berat, semakin cepat putaran jungkir balik. Saat atlet membuka dan melebarkan lengan dan kaki, putaran banyak berkurang. Gaya menggantung dan menyentak memberikan pengaruh yang sama untuk lompat jauh.

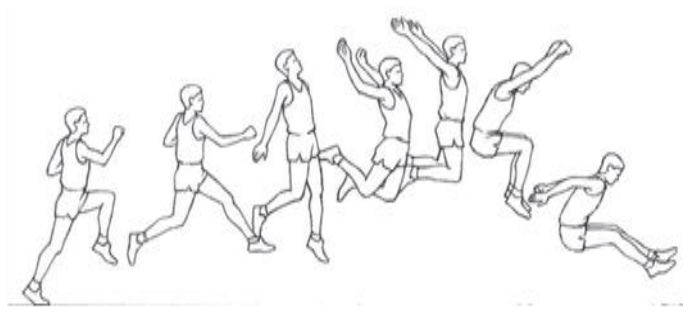

Gambar 8. Fase Gerakan Melayang di Udara

Sumber : Will Freeman, Track and Field

Coaching Essentials (USA : Human Kinetics, 2015)

\section{Mendarat}

Gerakan ini menyebabkan reaksi dengan tubuh bagian bawah, batang kaki, dan bola kaki menjulur ke depan. Tumit menyentuh pasir dan harus menekuk lutut untuk memungkinkan pangkal paha bergerak ke depan, sementara itu kedua lengan terayun turun dan ke belakang.

\section{DAYA LEDAK OTOT TUNGKAI}

Daya ledak dapat diartikan kemampuan daya maksimal dalam waktu tercepat. Daya eksplosif atau daya ledak adalah suatu kemampuan gerak yang sangat penting untuk menunjang aktivitas pada setiap cabang olahraga. Kemampuan daya ledak ini akan menentukan hasil gerak yang baik. Suatu contoh : jika seseorang memiliki daya eksplosif yang baik maka akan menghasilkan tendangan yang keras, atau seorang pelari cepat akan menghasilkan larinya yang lebih cepat.

Bresnahan dan Tuttle dijelaskan bahwa dalam rangka memperoleh jarak untuk melompat, kita harus menggabungkan momentum dengan tinggi. Momentum diperoleh melalui kecepatan lari, sementara ketinggian diperoleh melalui daya ledak yang di dapat dari tolakan di papan take-off. Kekuatan pegas tergantung pada kekuatan kaki, tungkai, dan otot paha untuk merespon secara efisien dan cepat. Pentingnya daya 
ledak otot tungkai pada saat melakukan gerakan melompat pada nomor lompat jauh, dikarenakan pada saat gerakan tolakan untuk mencapai suatu ketinggian yang lebih dominan berperan adalah gerakan yang bersifat eksplosif.

Adapun model latihan untuk meningkatkan daya ledak bisa dengan latihan plyometrik; yaitu latihan lompatan dengan ketinggian bertahap, dengan melakukan latihan penguatan otot tungkai terlebih dahulu dan penguatan sendi-sendi sehingga atlet mampu melakukan model latihan plyometrik karena latihan ini apabila diberikan kepada atlet yang tidak terlatih akan menyebabkan cedera yang cukup fatal yang membuat atlet harus beristirahat atau bahkan sampai penanganan dokter bedah.

Power otot seseorang tersebar diberbagai alat gerak yang dimiliki oleh bagian-bagian tubuh termasuk tungkai. Tungkai menurut Hardianto Wibowo adalah salah satu dari anggota badan bawah yang dibagi menjadi dua bagian yaitu tungkai atas dan tungkai bawah. Fungsi tungkai sangatlah penting, dalam hal ini dapat kita lihat dalam kehidupan sehari-hari dimana pada saat kita jatuh atau mendarat ke tanah tungkai akan menahan badan kita dan pada saat kita melompat tungkai akan memberikan kekuatan yang besar seperti dikelaskan di atas tungkai menjadi dua yaitu tungkai bawah bagian bawah. Tungkai atas dibentuk oleh kaput femoris dan artikulasio koxae, sedangkan tungkai bagian bawah dibentuk oleh tulang tibia dan tibula yang bersatu dalam artikulasio.

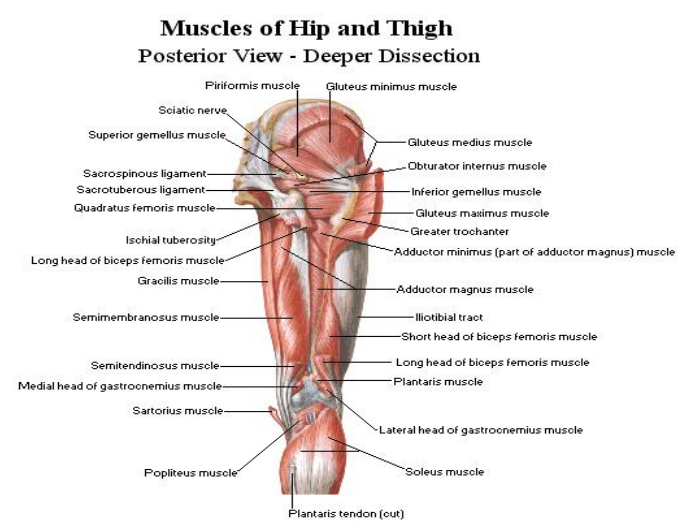

Gambar 10. Foto Tungkai Atas

Sumber:http://www.kaskus.co.id/show_post /000000000000000753893669/14

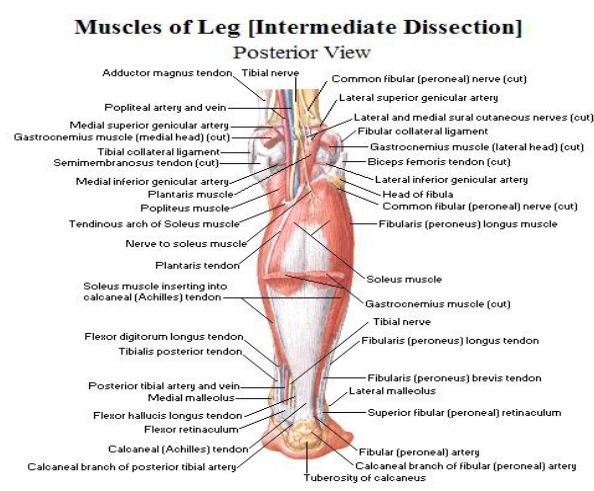

Gambar 11. Foto Tungkai Bawah

Sumber:http://www.kaskus.co.id/show_post

/000000000000000753893669/14

Dari berbagai definisi di atas dapat disimpulkan bahwa power adalah kemampuan untuk mengerahkan kekuatan maksimal dalam waktu yang sangat cepat yang dihasilkan oleh sekelompok otot untuk mengatasi tahanan beban dengan kekuatan yang maksimal dan kecepatan yang tinggi dalam suatu gerakan. Untuk itu, urutan latihan untuk meningkatkan power diberikan setelah olahragawan dilatih unsur kekuatan dan kecepatan.

\section{Kecepatan Lari}

Kemampuan untuk melakukan gerakan-gerakan yang sejenis secara berturut-turut dalam waktu yang singkat, atau kemampuan untuk menempuh suatu jarak dalam waktu yang sesingkatsingkatnya. Kecepatan adalah kemampuan otot atau sekelompok otot untuk menjawab rangsang dalam waktu secepat (sesingkat) mungkin. Dengan kata lain kecepatan merupakan kemampuan seseorang untuk menjawab rangsang dengan bentuk gerak atau serangkaian gerak dalam waktu secepat mungkin.

Kecepatan (speed) adalah perbandingan antara jarak dan waktu atau kemampuan untuk bergerak dalam waktu singkat. Elemen kecepatan meliputi: waktu reaksi, frekuensi gerak per satuan waktu, dan kecepatan gerak melewati jarak. Kecepatan menurut Jonath, Haag \& Kremple, kecepatan dilihat dari pembagian gerakan kecepatan dapat dibedakan menjadi 3 macam antara lain; kecepatan siklis, kecepatan asiklis, kecepatan dasar. 
a. Kecepatan Siklis adalah produk yang dihitung dari frekuensi gerak (misalnya frekuensi langkah amplitude gerak, contohnya panjang langkah). Apabila gerakan siklis mulai dengan kecepatan 0 (nol) pada pembagian isyarat mulai, dan jika waktunya dihitung dari pembagian isyarat-isyarat misalnya pada lari cepat jarak pendek, maka dapat dibedakan faktor-faktor sebagai berikut: waktu reaksi (start), percepatan gerak pada meter-meter pertama, kecepatan dasar sebagai kecepatan maksimal, maupun stamina kecepatan.

b. Kecepatan Asiklis, kecepatan ini dibatasi oleh faktor yang mengenai kecepatan gerak masing-masing otot dan yang terletak dalam otot. Tenaga statis ini dan kecepatan kontraksi yang menentukan cepatnya gerak. Kedua faktor tersebut selanjutnya tergantung pada viskositas dan tonus otot. Selain itu juga faktor-faktor luar memegang peranan, kerja antagonis otot dan pemelarannya sehubungan dengan itu, pangkal dan permulaan lagi otot tuas maupun massa yang digerakan (perbandingan bebantenaga). Faktor-faktor yang membatasi prestasi adalah tenaga dinamis (gaya cepat) ukuran antropometri (perbandingan badantuas) dan massa (perbandingan beban-tenaga)

c. Kecepatan Dasar sebagai kecepatan maksimal yang dicapai dalam gerak siklis adalah produk maksimal yang dapat dicapai dari frekuensi gerakan amplitudo gerak. Ini tidak dapat dibedakan menurut kecepatan gerak maju dan kecepatan gerak. Maksimum kecepatan dasar pada wanita dicapai pada usia antara 17 dan 22 tahun, pada pria antara 19 dan 23 tahun. Faktor-faktor yang membatasi adalah: tenaga, vikositas, otot, kecepatan kontraksi, ukuran antropometris, koordinasi, stamina dan waktu reaksi.
Berdasarkan penjelasan teori di atas maka dapat disimpulkan bahwa kecepatan yang berperan dalam keterampilan lompat jauh gaya menggantung adalah kecepatan siklis. Kecepatan siklis tersebut berbentuk awalan lari yang dihitung melalui frekuensi langkah yang didorong oleh kecepatan. Kecepatan dasar juga berperan penting dalam keterampilan lompat jauh. Keterampilan dasar berperan dalam kecepatan maksimal yang didapat dari awalan lari saat mendekati papan tolakan.

Awalan dalam lompat jauh gaya jongkok adalah suatu gerakan yang dilakukan dengan cara berlari secepatcepatnya agar dapat menghasilkan kecepatan yang setinggi-tingginya sebagai awalan sebelum melakukan tolakan. Selanjutnya kecepatan dan ketepatan dalam lari awalan, sangat mempengaruhi pada hasil lompatan ini berarti bahwa kecepatan lari awalan adalah suatu keharusan untuk mencapai hasil yang sebaik-baiknya.

Seperti yang dikutip dari buku peraturan atletik yang berjudul International Association Athletics Federation Competition Rules : Panjang minimum untuk awalan lari, diukur dari lepas landas relevan take off line yaitu $40 \mathrm{~m}$ dan jika kondisi memungkinkan yaitu $45 \mathrm{~m}$. Lebar lintasan sekitar $1.22 \mathrm{~m}( \pm 0.01 \mathrm{~m})$ dan harus ditandai dengan garis putih setebal $5 \mathrm{~cm}$.

Dalam melakukan keterampilan lompat jauh gaya menggantung, kecepatan sangat berhubungan dengan proses melakukan awalan seperti yang dikutip dalam buku Track and Field Third Edition yang dikarang oleh Bresnahan dan Tuttle yaitu tipe kecepatan, dalam tipe ini pelompat bergantung pada kemampuan berlari cepatnya dan ini selalu digunakan untuk unggul dalam awalan.

Karena untuk melakukan lompat jauh diperlukan sebuah awalan yang menggunakan kecepatan. Saat mendekati papan tolakan maka yang diperlukan adalah kecepatan yang tinggi, semakin mendekati papan tumpuan maka kecepatan harus ditambah tanpa mengurangi kecepatan sedikitpun. 
Dalam melakukan awalan dalam lompat jauh diperlukan strategi penggunaan kecepatan. Umumnya dalam melakukan awalan terbagi menjadi 3 area penggunaan kecepatan yaitu $1 / 2$ speed, $3 / 4$ speed, dan 95/100 speed. Semakin mendekati papan tolakan kecepatan berlari harus ditambah tanpa mengurangi kecepatan sedikitpun. Ini dilakukan untuk menjaga irama langkah agar saat menumpu di papan tolakan tidak terjadi kesalahan sedikit pun.

Tujuan awalan adalah untuk mengembangkan gerakan kecepatan yang konsisten sambil mencapai kecepatan maksimum saat take off. Kecepatan saat melakukan tolakan merupakan hal penting karena kedua faktor yang menentukan jarak melayang adalah kecepatan lari dan sudut tolakan. Memahami cara menetapkan jarak awalan yang tepat untuk secara konsisten mencapai kecepatan maksimum saat bertolak merupakan hal yang penting.

Jika kaki atlet menyentuh garis ini, lompatan tersebut dianggap tidak sah dan tidak diukur. Demikian juga, jika atlet melompat beberapa sentimeter atau lebih di depan garis yang tidak sah tersebut, lompatan itu dianggap sah, tetapi pelompat kehilangan jarak dari lompatan sesungguhnya, karena lompatan diukur dari garis lompatan atau garis tidak sah.

Maka dari itu untuk mendapatkan lompatan yang paling baik, perlu diperhatikan untuk pelompat a gar mendapatkan konsisten dan akurasi dalam melakukan gerakan dan semaksimal mungkin dekat dengan papan tolakan.

\section{KERANGKA BERPIKIR}

1. Hubungan Antara Kecepatan Lari dengan Hasil Lompat Jauh Gaya Menggantung Pada Mahasiswa Kuliah Olahraga Prestasi Atletik Fakultas Ilmu Keolahragaan Universitas Negeri Jakarta

Kecepatan adalah kemampuan tubuh dalam melakukan gerakan-gerakan yang sejenis atau perpindahan dari titik satu ke titik lain dengan waktu yang sesingkatsingkatnya. Kecepatan pada lompat jauh berperan saat melakukan awalan. Kecepatan akan memberikan dorongan pada saat melakukan awalan lari. Awalan berfungsi sebagai dorongan dalam persiapan melakukan tolakan pada papan tumpuan. Saat mendekati papan tolakan kecepatan tidak boleh dikurangi. Ini bertujuan agar mendapatkan kecepatan maksimal yang akan ditambahkan dengan kekuatan tolakan yang semaksimal mungkin dan yang merupakan hubungan yang berarti antara kecepatan lari dan hasil lompat jauh gaya menggantung.

Kecepatan berlari dari otot tungkai juga menjadi pengaruh dalam hasil lari cepat 20 meter dikarenakan ketika pelari memulai langkah dan memperkecil angka yang keluar sehingga mencapai tujuan dari penelitian. Karena reaksi dari pelari yang dihasilkan kecil maka menambah kualitas dari hasil maksimal lari cepat 20 meter yang diujikan oleh peneliti yang menjadi variabel bebas yang mengikat hasil lompat jauh gaya menggantung sebagai variabel terikat.

Oleh karena itu kecepatan berlari berperan penting dalam proses menuju tolakan pada lompat jauh gaya menggantung.

\section{Hubungan Antara Daya Ledak Otot Tungkai dengan Hasil Lompat Jauh Gaya Menggantung Pada Mahasiswa Kuliah Olahraga Prestasi Atletik Fakultas Ilmu Keolahragaan Universitas Negeri Jakarta}

power tungkai adalah kemampuan otot untuk meledakkan tenaga pada tungkai secara maksimal dalam waktu yang singkat. Dengan demikian power tungkai sangat mempengaruhi tolakan pada saat melakukan take-off, untuk dapat melakukan tolakan dibutuhkan power tungkai yang kuat.

Kemampuan otot tungkai dalam melakukan gerak eksplosif otot akan berpengaruh besar dalam pelaksaan dan hasil tolakan pada saat akan melompat. Berhubungan dengan daya ledak otot tungkai maka dalam hal ini otot tungkai berperan sangat besar dalam melakukan tolakkan untuk mendapat sudut pencapaian maksimal dari hasil lompat jauh gaya 
menggantung. Saat melakukan tolakan diperlukan daya ledak otot kaki yang baik, dari otot tungkai sesaat setelah menginjak papan take-off yang menjadi stimulus. Dengan daya ledak yang maksimal maka diharapkan dapat menghasilkan hasil tolakkan maksimal dan dapat menghasilkan gerakan melayang di udara yang baik pula.

Daya ledak akan membantu posisi tubuh untuk melayang udara, saat melayang di udara posisi tubuh dalam keadaan menggantung dengan posisi badan condong ke belakang, posisi tungkai ditekuk ke belakang rileks, posisi lengan lurus ke atas. Lalu dilanjutkan meluruskan kaki ke depan dan membawa lengan ke depan untuk persiapan posisi mendarat. Gerakan-gerakan barusan memerlukan daya ledak yang baik agar dapat berlajan dengan baik.

3. Hubungan Kecepatan Lari Dan Daya Ledak Otot Tungkai dengan Hasil Lompat Jauh Gaya Menggantung Mahasiswa Kuliah Olahraga Prestasi Atletik Fakultas Ilmu Keolahragaan Universitas Negeri Jakarta

Di dalam nomor lompat jauh gaya menggantung terdapat aspek-aspek penunjang dalam keberhasilan dalam melaksanakan hasil gerakan tersebut. Terdapat teknik awalan, teknik tolakan, teknik saat di udara, dan teknik saat mendarat. Selain itu terdapat unsur- unsur lain seperti kecepatan lari dan daya ledak otot tungkai. Kedua unsur tersebut berpengaruh dan memberi sumbangan besar dalam pelaksanaan lompat jauh gaya menggantung.

Begitu juga dengan mahasiswa melakukan tolakan pada papan tolakan dengan posisi tubuh yang benar, maka akan tercipta daya ledak yang menghasilkan lompatan yang jauh dengan angka yang tinggi pula. Hingga akhirnya dilanjutkan dengan gerakan melayang di udara dan diakhiri oleh posisi mendarat. Itu semua adalah proses lompat jauh gaya menggantung.

\section{PENGAJUAN HIPOTESIS}

1. Terdapat hubungan kecepatan lari dengan hasil lompat jauh gaya menggantung pada mahasiswa Klub Olahraga Prestasi Atletik Fakultas Ilmu Keolahragaan Universitas Negeri Jakarta.

2. Terdapat hubungan daya ledak otot tungkai dengan hasil lompat jauh gaya menggantung pada mahasiswa Klub Olahraga Prestasi Atletik Fakultas Ilmu Keolahragaan Universitas Negeri Jakarta

3. Terdapat hubungan kecepatan lari dan daya ledak otot tungkai dengan hasil belajar lompat jauh gaya menggantung di mahasiswa Klub Olahraga Prestasi Atletik Fakultas Ilmu Keolahragaan Universitas Negeri Jakarta.

\section{HASIL PENELITIAN}

Deskripsi data di bawah ini dimaksudkan untuk memperoleh gambaran tentang penyebaran data yang meliputi nilai terendah, nilai tertinggi, rata-rata, simpangan baku, modus, distribusi frekuensi, varians, serta histogram dari masing-masing variabel $\mathrm{X} 1, \mathrm{X} 2$ dan $\mathrm{Y}$.

Berikut data lengkapnya :

Tabel 4. Deskripsi Data Penelitian

\begin{tabular}{|l|l|l|l|}
\hline Variabel & $\begin{array}{l}\text { Daya } \\
\text { Ledak } \\
\text { Otot } \\
\text { Tungkai } \\
\mathbf{X}_{\mathbf{1}}\end{array}$ & $\begin{array}{l}\text { Kecepatan } \\
\mathbf{X}_{\mathbf{2}}\end{array}$ & $\begin{array}{l}\text { Hasil } \\
\text { Lompat } \\
\text { Jauh } \\
\mathbf{Y}\end{array}$ \\
\hline $\begin{array}{l}\text { Nilai } \\
\text { terendah }\end{array}$ & 2,70 & 1,92 & 3,16 \\
\hline $\begin{array}{l}\text { Nilai } \\
\text { tertinggi }\end{array}$ & 4,19 & 2,99 & 6 \\
\hline Rata-rata & 3,32 & 2,48 & 5,09 \\
\hline $\begin{array}{l}\text { Simpangan } \\
\text { baku }\end{array}$ & 0,35 & 0,25 & 0,64 \\
\hline Varians & 0,12 & 0,06 & 0,41 \\
\hline
\end{tabular}

Variabel Kecepatan (X1)

Hasil penelitian menunjukkan rentang skor kecepatan (X1) adalah antara 2,70 detik sampai dengan 4,19 detik nilai rata-rata sebesar 3,32 detik simpangan baku sebesar 0,35. Distribusi Frekuensi dapat dilihat pada tabel 5 di balik ini: 
Tabel 5. Distribusi Frekuensi Kecepatan

\begin{tabular}{|c|c|c|c|c|}
\hline \multirow{2}{*}{ No } & \multirow{2}{*}{$\begin{array}{c}\text { Interval } \\
\text { Kelas }\end{array}$} & \multirow{2}{*}{$\begin{array}{l}\text { Titik } \\
\text { Tengah }\end{array}$} & \multirow{2}{*}{$\begin{array}{l}\text { Frekuensi } \\
\text { Absolut }\end{array}$} & \multirow[b]{2}{*}{$\begin{array}{c}\begin{array}{c}\text { Relatif } \\
(\%)\end{array} \\
\end{array}$} \\
\hline & & & & \\
\hline 1 & $\begin{array}{l}2,7- \\
3,00\end{array}$ & 2,85 & 3 & 10 \\
\hline 2 & $\begin{array}{c}3,01- \\
3,31\end{array}$ & 3,16 & 16 & 53,33 \\
\hline 3 & $\begin{array}{c}3,32- \\
3,62\end{array}$ & 3,47 & 6 & 20 \\
\hline 4 & $\begin{array}{c}3,63- \\
3,93\end{array}$ & 3,78 & 3 & 10 \\
\hline \multirow[t]{2}{*}{5} & $\begin{array}{c}3,94- \\
4,24 \\
\end{array}$ & 4,09 & 2 & 6,67 \\
\hline & Jumlah & & 30 & 100 \\
\hline
\end{tabular}

Berdasarkan tabel 5 di atas dibandingkan dengan nilai rata-rata, terlihat testee yang berada pada kelas rata-rata sebanyak 6 testee (20\%) dan yang berada di bawah kelas rata-rata sebanyak 5 testee $(16,67 \%)$, sedangkan testee yang berada di atas kelas rata-rata sebanyak 19 testee $(63,33 \%)$. Selanjutnya histogram variabel kecepatan dapat dilihat pada gambar di bawah ini :

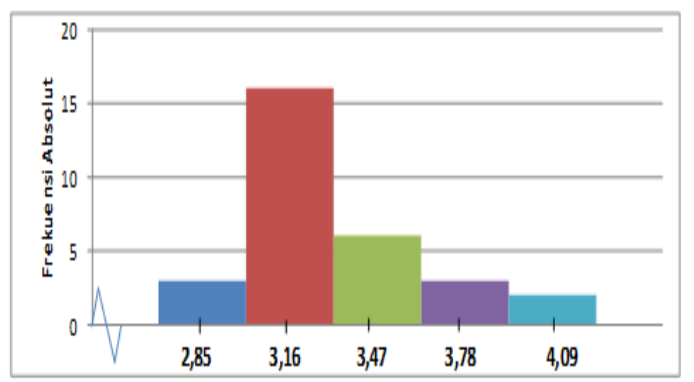

Gambar 13. Grafik Histogram Data Kecepatan $\left(X_{2}\right)$

Variabel Daya Ledak Otot Tungkai (X2)

Hasil penelitian menunjukkan rentang skor daya ledak otot tungkai (X1) adalah antara 1,92 meter sampai dengan 2,99 meter, nilai rata-rata sebesar 2,48 meter, simpangan baku sebesar 0,25. Distribusi Frekuensi dapat dilihat pada tabel 6 di bawah ini.

Tabel 6.Distribusi frekuensi daya ledak otot tungkai (X2)

\begin{tabular}{|c|c|c|c|c|}
\hline \multirow{2}{*}{ No } & \multirow{2}{*}{ Interval Kelas } & Titik Tengah & \multicolumn{2}{|c|}{ Frekuensi } \\
\cline { 4 - 5 } & & & Absolut & Relatif (\%) \\
\hline 1 & $1,92-2,14$ & 2,99 & 3 & 10 \\
\hline 2 & $2,15-2,37$ & 3,33 & 5 & 16,67 \\
\hline 3 & $2,38-2.60$ & 3,68 & 15 & 50 \\
\hline 4 & $2,61-2,83$ & 4,02 & 5 & 16,67 \\
\hline 5 & $2,84-3,06$ & 4,37 & 2 & 6,67 \\
\hline & Jumlah & & 30 & 100 \\
\hline
\end{tabular}

Berdasarkan data dari tabel 6 di atas dibandingkan dengan nilai rata-rata, terlihat testee yang berada pada kelas rata-rata sebanyak 15 testee (50\%) dan yang berada di bawah kelas rata-rata sebanyak 3 testee $(10 \%)$, sedangkan testee yang berada di atas kelas rata-rata sebanyak 7 testee $(23,34 \%)$. Selanjutnya historam variabel daya ledak otot tungkai dapat dilihat pada gambar di balik ini :

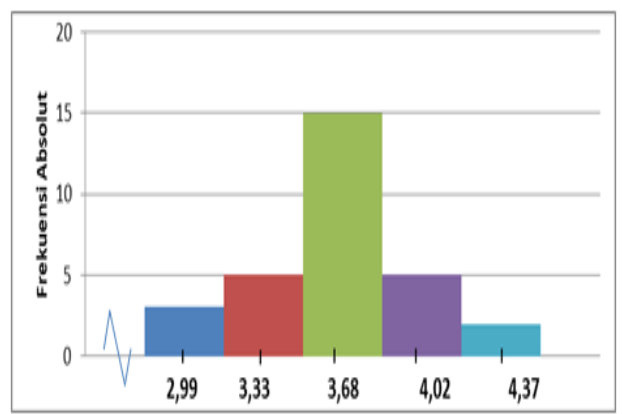

Gambar 14. Grafik Histogram Data Daya Ledak Otot Tungkai (X2)

Variabel Hasil Lompat Jauh Gaya Menggantung ( $\mathrm{Y}$ )

Hasil penelitian menunjukkan rentang skor hasil lompat jauh gaya menggantung (Y) adalah antara 3,16 sampai dengan 6 meter, nilai rata-rata sebesar 5,09 simpangan baku sebesar 0,64. Distribusi Frekuensi dapat dilihat pada tabel 7 di bawah ini :

Tabel 7. Distribusi Frekuensi Hasil Lompat Jauh Gaya Menggantung (Y)

\begin{tabular}{|c|c|c|c|c|}
\hline \multirow{2}{*}{ No } & \multirow{2}{*}{ Interval Kelas } & \multirow{2}{*}{ Titik Tengah } & \multicolumn{2}{|c|}{ Frekuensi } \\
\cline { 4 - 5 } & & & Absolut & Relatif (\%) \\
\hline 1 & $3,16-3,64$ & 4,98 & 1 & $3,34 \%$ \\
\hline 2 & $3,65-4,13$ & 5,715 & 1 & $3,34 \%$ \\
\hline 3 & $4,14-4,62$ & 6,45 & 6 & $20 \%$ \\
\hline 4 & $4,63-5,11$ & 7,183 & 2 & $6,67 \%$ \\
\hline 5 & $5,12-5,60$ & 7,92 & 15 & $50 \%$ \\
\hline 6 & $5,61-6,09$ & 8,655 & 5 & $16,67 \%$ \\
\hline & Jumlah & & 30 & 100 \\
\hline
\end{tabular}

Berdasarkan tabel 7 di atas dibandingkan dengan nilai rata-rata, terlihat testee yang berada pada kelas rata-rata sebanyak 2 testee $(6,67 \%)$ dan yang berada di bawah kelas rata-rata sebanyak 8 testee $(26,68 \%)$, sedangkan testee yang berada di 
atas kelas rata-rata sebanyak 20 testee $(56,67$ $\%)$. Selanjutnya historam variabel hasil lompat jauh gaya menggantung dapat dilihat pada gambar di bawah ini :

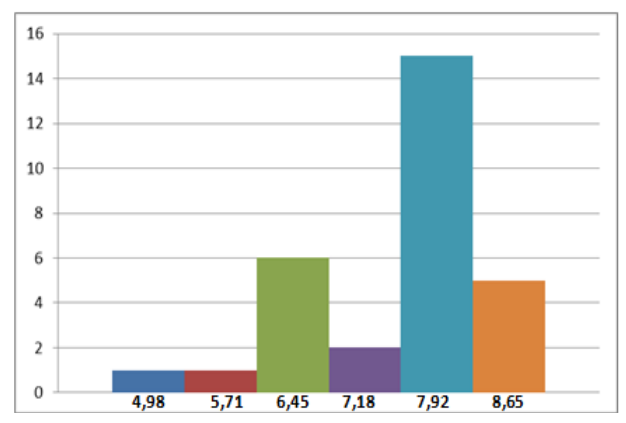

Gambar 15. Grafik Histogram Data Hasil Lompat Jauh Gaya Menggantung (Y)

\section{PENGUJIAN HIPOTESIS}

1. Hubungan Kecepatan Lari dengan Hasil Lompat Jauh Gaya Menggantung.

Hubungan kecepatan lari dengan hasil lompat jauh gaya menggantung dinyatakan oleh persamaan regresi $=10,37$ - 1,59 X1. Artinya hasil lompat jauh gaya menggantung dapat diketahui atau diperkirakan dengan persamaan regresi tersebut, jika variabel kecepatan (X1) diketahui. Konstanta yang diperoleh bernilai berarti, ini menunjukkan hubungan yang berarti. Nilai pendugaan regresi sebesar 1,59 yang menunjukan besaran pengaruh kecepatan terhadap hasil lompat jauh.

Hubungan kecepatan (X1) dengan hasil lompat jauh gaya menggantung (Y) ditunjukan oleh koefisien korelasi ry1 = 0,87 . Koefisien korelasi tersebut harus diuji terlebih dahulu mengenai keberartiannya, sebelum digunakan untuk mengambil kesimpulan. Hasil uji koefisien korelasi tersebut dapat dilihat dalam tabel berikut :

Tabel 8. Uji Keberartian Koefisien Korelasi (X1) Terhadap (Y)

\begin{tabular}{|c|c|c|}
\hline Koefisien Korelasi & T.hitung & T.tabel \\
\hline$-0,87$ & 9,14 & 1,69 \\
\hline
\end{tabular}

Dari uji keberartian koefisien korelasi di atas terlihat bahwa t.hitung = 17,87 lebih besar dari t,tabel $=1,69$ berarti koefisien korelasi ry1 $=-0,87$ adalah signifikan. Nilai korelasi menunjukan nilai negatif, ini disebabkan karena variabel kecepatan memiliki karakteristik jika semakin kecil/cepat nilai (waktu) yang diperoleh maka semakin baik hasil lompat yang dihasilkan. Dengan demikian hipotesis yang mengatakan terdapat hubungan kecepatan lari dengan hasil lompat jauh gaya menggantung didukung oleh data penelitian. Yang berarti semakin baik kecepatan berlarinya akan baik pula hasil lompat jauh gaya menggantung. Koefisien determinasi kecepatan lari dengan hasil lompat jauh gaya menggantung $\left(\right.$ ry $\left.1^{2}\right)=0,749$ hal ini berarti bahwa $74,90 \%$ hasil lompat jauh gaya menggantung ditentukan oleh kecepatan (X1).

2. Hubungan Daya Ledak Otot Tungkai Dengan Hasil Lompat Jauh Gaya Menggantung

Hubungan daya ledak otot tungkai dengan hasil lompat jauh gaya menggantung dinyatakan oleh persamaan regresi $=0,35+$ 1,64 . Artinya hasil lompat jauh gaya menggantung dapat diketahui atau diperkirakan dengan persamaan regresi tersebut, jika variabel daya ledak otot tungkai (X2) diketahui. Konstanta yang diperoleh bernilai berarti, ini menunjukkan hubungan yang berarti. Nilai pendugaan regresi sebesar 1,64 yang menunjukan besaran pengaruh daya ledak terhadap hasil lompat jauh.

Hubungan daya ledak otot tungkai (X2) dengan hasil lompat jauh gaya menggantung (Y) ditunjukan oleh koefisien korelasi ry1 $=0,75$. Hasil uji koefisien korelasi tersebut dapat dilihat dalam tabel berikut :

Tabel 9. Uji Keberartian Koefisien Korelasi (X2) Terhadap (Y)

\begin{tabular}{|c|c|c|}
\hline Koefisien Korelasi & T.Hitung & T.Tabel \\
\hline 0,75 & 6,08 & 1,69 \\
\hline
\end{tabular}


Dari uji keberartian koefisien korelasi di atas terlihat bahwa t.hitung $=6,08$ lebih besar t,tabel $=1,69$ berarti koefisien korelasi ry2 $=0,75$ adalah signifikan. Dengan demikian hipotesis yang mengatakan terdapat hubungan daya ledak otot tungkai dengan hasil lompat jauh gaya menggantung didukung oleh data penelitian. Yang berarti semakin baik daya ledak otot tungkai akan baik pula hasil lompat jauh gaya menggantung. Koefisien determinasi daya ledak otot tungkai dengan hasil lompat jauh gaya menggantung adalah $\left(\mathrm{ry}^{2}\right)=$ 0,569 hal ini berarti bahwa 56,90\% hasil lompat jauh gaya menggantung ditentukan oleh daya ledak otot tungkai (X2).

3. Hubungan Kecepatan Lari Dan Daya Ledak Otot Tungkai dengan Hasil Lompat Jauh Gaya Menggantung Pada Mahasiswa Kop Atletik Universitas Negeri Jakarta.

Hubungan kecepatan (X1) dan daya ledak otot tungkai (X2) dengan hasil lompat jauh gaya menggantung $(\mathrm{Y})$ dinyatakan oleh persamaan regresi $\hat{Y}=7,87-1,27+0,82$. Nilai konstanta memiliki nilai yang berarti, ini menunjukan kecepatan lari dan daya ledak memiliki hubungan yang berarti dengan hasil lompat jauh. Jika daya ledak konstan, maka hasil lompat jauh mempengaruhi kecepatan sebesar -1,27. Jika hasil lompat jauh konstan maka daya ledak akan mempengaruhi kecepatan sebesar 0,82. Sedangkan hubungan ketiga variabel tersebut dinyatakan oleh koefisien korelasi ganda Ry1-2 $=0,88$. Koefisien korelasi ganda tersebut, harus di uji terlebih dahulu mengenai keberartiannya sebelum digunakan untuk mengambil kesimpulan. Hasil uji koefiesien korelasi ganda tersebut dapat dilihat dalam tabel berikut :

Tabel 10. Uji Keberartian Koefisien Korelasi Ganda

\begin{tabular}{|c|c|c|}
\hline Koefisien Korelasi & F.hitung & F.tabel \\
\hline 0,88 & 45,58 & 3,89 \\
\hline
\end{tabular}

Uji keberartian koefisien korelasi di atas terlihat bahwa F.hitung $=45,58$ lebih besar dari F.tabel $=3,89$. Berarti koefisien tersebut Ry1-2 $=0,88$ adalah signifikan.
Koefisien determinasi (Ry1.2.) $2=0,771$ hal ini berarti bahwa 77,10\% Hasil Lompat Jauh Gaya Menggantung ditentukan oleh kecepatan lari dan daya ledak otot tungkai. Pembahasan

Berdasarkan dari hasil penelitian yang telah dilakukan, maka dapat ditemukan hasil penelitian menunjukkan: pertama, Terdapat hubungan kecepatan lari dengan hasil lompat jauh gaya menggantung, dengan persamaangaris linier $=10,37-1,59$ , koefisien korelasi (ry2) $=0,87$, yang berarti tingkat hubungannya masuk dalam kategori tinggi. Koefisien determinasi $\left(\right.$ ry $\left.1^{2}\right)=0,749$ yang berarti variabel kecepatan memberikan sumbangan dengan hasil lompat jauh gaya menggantung sebesar $74,90 \%$.

Kedua, terdapat hubungan daya ledak otot tungkai dengan hasil lompat jauh gaya menggantung, dengan persamaan garis linier $\hat{Y}=0,35+1,64 \mathrm{X} 2$, koefisien korelasi (ry1) $=0,75$, yang berarti tingkat hubungannya masuk dalam kategori sangat tinggi. Koefisien determinasi $\left(\right.$ ry $\left.1^{2}\right)=0,569$, yang berarti variabel daya ledak otot tungkai memberikan sumbangan terhadap hasil lompat jauh gaya menggantung sebesar $56,90 \%$.

Ketiga, terdapat hubungan kecepatan lari dan daya ledak otot tungkai dengan hasil lompat jauh gaya menggantung, dengan persamaan garis linier $\hat{\mathrm{Y}}=7,87-1,27+0,82$, koefisien korelasi Ry1-2 $=0,88$, yang berarti tingkat hubungannya masuk dalam kategori sangat tinggi. Koefisien determinasi $(\text { Ry1-2 })^{2}=$ 0,771 yang berarti variabel kecepatan lari dan daya ledak otot tungkai dengan hasil lompat jauh gaya menggantung memberikan sumbangan sebesar $77,10 \%$.

Dalam penelitian ini kecepatan lari dan daya ledak otot tungkai secara bersamasama memberikan kontribusi sebesar $77,10 \%$ pada hasil lompat jauh gaya menggantung. Sisanya sebesar 23,90\% ditentukan oleh faktor lainnya. Faktor-faktor yang dapat mempengaruhi hasil lompat jauh gaya menggantung adalah kekuatan, keseimbangan, koordinasi mata tangan kaki, tinggi badan dan panjang tungkai. 


\section{KESIMPULAN}

Berdasarkan hasil penelitian maka peneliti dapat menarik kesimpulan sebagai berikut:

1. Terdapat hubungan yang berarti antara kecepatan lari dengan hasil lompat jauh gaya menggantung pada mahasiswa Klub Olahraga Prestasi Atletik Fakultas Ilmu Keolahragaan Universitas Negeri Jakarta.

2. Terdapat hubungan yang berarti antara daya ledak otot tungkai dengan hasil lompat jauh gaya menggantung pada mahasiswa Klub Olahraga Prestasi Atletik Fakultas Ilmu Keolahragaan Universitas Negeri Jakarta.

3. Terdapat hubungan yang berarti antara kecepatan lari dan daya ledak otot tungkai dengan hasil lompat jauh gaya menggantung pada mahasiswa Klub Olahraga Prestasi Atletik Fakultas Ilmu Keolahragaan Universitas Negeri Jakarta.

\section{SARAN}

Berdasarkan kesimpulan dan hasil penelitian, maka dapat diajukan saran sebagai berikut:

1. Kecepatan atau speed adalah salah satu bakat dasar yang tidak dapat dilatih seperti teknik, apabila seorang pelatih hendak mencari atlet lompat jauh maka pelatih harus mengetahui jenis serabut otot atlet. Karena dalam melakukan lompat jauh gaya menggantung, kecepatan sangat dibutuhkan khususnya pada saat melakukan awalan lari yang berguna untuk mendapatkan tolakan yang jauh. Dalam cabang olahraga atletik seperti lompat jauh, kemampuan fisik daya ledak sangat perlu diperhatikan. Salah satunya daya ledak otot tungkai yang sangat berguna untuk melakukan teknik tolakan pada lompat jauh. Selain itu diperlukan juga kualitas otot tungkai yang dapat memberikan tolakan dengan hasil yang maksimal. Untuk pelatih mencari atlet lompat jauh dapat menggunakan variabel yang telah diuji sebagai scouting talent untuk bakat atlet atau calon atlet sehingga tidak membuang waktu melatih atlet yang kurang berbakat.

2. Para pelatih di Klub Olahraga Prestasi Atletik Fakultas Ilmu Keolahragaan Universitas Negeri Jakarta khususnya untuk dapat meneliti unsur-unsur lain yang dapat meningkatkan prestasi atlet lompat jauh dalam perlombaan.

\section{DAFTAR PUSTAKA}

Bresnahan and Tuttle, Track and Field Athletics Third Edition,USA:CV Mosby Company,

Djoko Pekik Irianto, Dasar Kepelatihan, Jogjakarta: FIK, UNY,2002

Djumidar A, Widya, Belajar Berlatih GerakGerak Dasar Atletik Dalam Bermain,Jakarta : CV, Gramada Offset,2002

http://capoecini,multiply,com/journal/item/ 41 ?\&show_interstitial $=1 \& \mathrm{u}=\% 2 \mathrm{Fj}$ ournal\%2Fitem, (Yang diakses pada Kamis, 29 November 2016)

http://fcomp2010,blogspot,com/2012/01/ma kalah-lompat-jauh,html,(Yang diakses pada 11 Desember 2016,)

http://www,sarjanaku,com/2011/09/lompatjauh-pengertian-teknik-faktor,html, (Yang diakses pada 11 Desember 2012,)

http://myyubi,blogspot,com/2013/07/lompa t-jauh-pengertian-teknik-danfaktor,html, (Yang diakses pada 14 Juni 2014)

International Association Athletics Federation Competition Rules 2012-2013 Centenary Edition, Monaco: 2011

Jarver, Jess, Belajar dan Berlatih Atletik, Bandung: CV Pionir Jaya, 2008

Moeslim, Tes dan Pengukuran Kepelatihan, Jakarta : Komite Olahraga Nasional Indonesia Pusat, 1995

Pedoman Penulisan Ilmiah, Jakarta: Universitas Negeri Jakarta, 2000

Riduwan, Belajar Mudah Penelitian Untuk Guru, Karyawan Dan Peneliti Pemula, Bandung: Alfabeta, 2010 